\title{
Effect of Chitosan, Salicylic Acid and Fulvic Acid on Vegetative Growth, Yield and Fruit Quality of Thompson Seedless Grapevines
}

\author{
M. A. El-Kenawy \\ Viticulture Department, Horticulture Research Institute, Agricultural Research Centre, Cairo, \\ Egypt.
}

\begin{abstract}
THIS STUDY was achieved out during two successive seasons (2015 \& 2016) The experiment was conducted on 16-year-old Thompson seedless grapevines. The vines were grown in a clay soil under surface irrigation system. Three material namely Chitosan, Salicylic acid and Fulvic acid applied at rate $(500 \mathrm{ppm})$ were used as a spray application either single or in combination of them on the vine for three times, at growth start, one week after berry set and at veraison as an attempt to develop growth, berry quality and enhancement storage shelf life period of Thompson seedless grapevines.

The Results appeared that single applications of Chitosan ,Salicylic acid and Fulvic acid or in combination of them were effective in improving shoot length, leaf surface area, total chlorophyll in the leaf and total protein in the canes in addition percentages of $\mathrm{N}, \mathrm{P}$ and $\mathrm{K}$ in the leaves as well as enhancing yield per vine, cluster weight, berry weight, soluble solids content and total phenols while reducing total acidity, cluster weight 10 ss $\%$, berry shatter $\%$ and berry decay $\%$ and total loss in cluster weight percentages during storage shelf life period. Also, enhanced berry adherence strength as compared with control in both seasons of study. Application of Chitosan + Salicylic acid + Fulvic acid was superior to using applications of Chitosan, Salicylic acid and Fulvic acid alone. In addition, the best results with regard to net profit of Thompson seedless grapevines were obtained when vines were sprayed with salicylic acid + fulvic acid.
\end{abstract}

Keywords: Grapevines, Thompson, Chitosan, Salicylic acid, Fulvic acid, storage, growth and chemical propertie.

\section{Introduction}

Grape (Vitis vinifera, L.) is considered the first fruit yield in both area and production all over the world. In Egypt it is the second main fruit after citrus. Thompson seedless grape is very important grape cultivar grown in Egypt. It is one of the most delicious, refreshing and nourishing subtropical fruits. The berries are a good source of minerals and vitamins (B1, B2 and C). The berries are consumed in fresh forms as a table fruit and in the processed form as wine, raisin and fresh juice. Thompson seedless is gaining more popularity both as table purpose and raisin making because of its high total soluble solids, thin skin and desired shape

Chitosan coating on caller fresh fruits can provide modified atmosphere storage and decrease quality changes through control of the internal gas composition of the fruits. The coating offers a protective barrier against bacterial contamination and moisture transfer to extend the shelf life Ghasemnezhad et al. (2013).

Jiang and $\mathrm{Li}$ (2001) reported that chitosan coatings help to reduce transpiration and control weight loss to slow down ripening and expand shelf life by controlling respiration rate and ethylene production. Also,Adwiger (2013) should that the agricultural and horticultural uses for chitosan, primarily for plant defense and yield increase, are based on how this glucosamine polymer influences the biochemistry and molecular biology of the plant cell. Recently, some researchers reported that chitosan enhanced plant development such as Shehata et al. (2012), Shiri et al. (2013) and Wafaa et al. (2014).

Hayat and Ahmad (2007) reported that Salicylic acid is a phenolic phytohormone and is found in plants with roles in plant growth and development, photosynthesis, ion uptake and transport. Salicylic acid also stimulate induces 
specific modifications changes in leaf and chloroplast structure. Vlot et al. (2009) revealed that salicylic acid is considered as a secondary plant hormone because of its role in regulating some aspects of disease resistance in plants. Hayat et al. (2010) found that salicylic acid was responsible for protecting the plants from all stresses and retarding reactive oxygen forms that destroyed the plant cells. Also, found that treating the trees with salicylic acid was very effective in enhancing metabolism of plants and the biosynthesis of all organic food.

Using salicylic acid at $400 \mathrm{ppm}$ three times was high very effective in amendment growth, yield and fruit quality in most evergreen fruit crops Ahmed, (2011), Abd El- Rahman \& ElMasry,( 2012) and Ahmed et al., (2014).

Fulvic acid is very effective because of its least molecular weight, it has necessary and capacity to readily bond minerals and elements into its molecular structure causing them resolve and be become mobilized fulvic complexes, Fulvic acid usually loads 70 or more mineral and effect elements as bit of its molecular complexes, Aiken et al. (1985) reported that Fulvic acids are key ingredients of enhance quality foliar fertilizers. As they can help the permeation to the plant parts, stimulate the absorption uptake of mineral from plant surfaces into plant tissues.

Once applied to leaves, fulvic acid bearer transport trace minerals directly to metabolic locations inside plant cells. Subsequently, foliar spray using at specific plant growth stages, containing mineral chelated can be used as a primary technique for maximizing plants productive capacity Chen et al. (2004).

The target of this study is to improve vegetative growth, yield, quality and storage of Thompson seedless grapevines by using Chitosan, salicylic acid and fulvic acid.

\section{Materials and Methods}

This investigation was carried out during successive seasons (2015 and 2016) in a private vineyard at El-deer village, Aga, Dakahlia Governorate, Egypt. The experiment was conducted on sixteen years old Thompson seedless grapevines. Vines were cultivated at $2 \times 2 \mathrm{~m}$. in a clay soil as cleared in Table 1 under surface irrigation system. The vines were trained cane under three wires trellis system. During January of each experimental season, the tested vines were pruned to 6 canes with 12 eyes each along with 6 renewal spurs. The total bud load was 84 buds. Seventy two vines uniform in vigor as possible were chosen for this study, all vines received the same cultural managements recommended by ministry of agriculture. The experiment consisted of eight treatments arranged in a randomized complete blocks design, each treatment include three replicates, each made of three vines.

TABLE 1. Mechanical and chemical analysis of the experimental soil at the depth of $(0-90 \mathrm{~cm})$.

\begin{tabular}{lll}
\hline & Clay (\%) & 49.15 \\
Mechanical & Silt (\%) & 25.69 \\
& Sand (\%) & 25.16 \\
& Texture & Clay \\
\hline \multirow{5}{*}{ Chemical } & O.M. (\%) & 2.0 \\
& pH & 7.9 \\
& E.C.( 1:5 extract) (Mmhos/cm) & 0.61 \\
& N (ppm) $(\%)$ & 1.83 \\
& P (ppm) & 36 \\
& K (ppm) & 13 \\
\hline
\end{tabular}

Three materials such as Chitosan a mostly deacetylated $\quad \beta$-(1-4)-linked D-glucosamine polymer, Salicylic acid $\mathrm{C}_{7} \mathrm{H}_{6} \mathrm{O}_{3}$ and Fulvic acid (Fulvic acid $60 \%$ +Potassium $1.0 \%$ )were foliar applied at rate $(500 \mathrm{ppm})$ on the vine for three times, at growth start, one week after fruit set and at version. Treatments applied as follow:

- Control spraying with (tap water)

- Spraying with chitosan

- Spraying with salicylic acid

- Spraying with fulvic acid

- Spraying with chitosan + fulvic acid

- Spraying with chitosan + salicylic acid

- Spraying with salicylic acid + fulvic acid

- Spraying with chitosan + fulvic acid + salicylic acid 
The following characteristics were determined Vegetative growth parameters

Vegetative growth parameters were taken from non bearing shoots and determined at two weeks after fruit set (after the second spray) as follows:

Measurements during vegetative growth Average shoots length $(\mathrm{cm})$

Shoot length was calculated by measuring the rate length of 4 shoots / vine (shoot from each side)

\section{Average leaf area $\left(\mathrm{cm}^{2} /\right.$ leaf)}

Representative sample of four mature leaves per each treated vine $\left(6^{\text {th }}\right.$ or $\left.7^{\text {th }}\right)$ leaf from the top of the same previous shoots) that were taken from the different vine sides and used for leaf surface area measurements according to the following equation Montero et al. (2000):

Leaf surface area $\left(\mathrm{cm}^{2} /\right.$ leaf $)=0.587(\mathrm{~L} \mathrm{x} \mathrm{W})$

Where, $\mathrm{L}=$ Length of leaf blade, $\mathrm{W}=$ Width of leaf blade

\section{Total Chlorophyll content in the leaves}

Sixth and seventh leaves from the tip of the growing shoots were used for the determination of total chlorophyll content in the leaves at two weeks after fruit set according to the methods described by Mackinny (1941) total chlorophyll was calculated as $\mathrm{mg} / \mathrm{g}$ fresh weight.

\section{$N, P$ and $K$, content in the leaves}

Two weeks after fruit set, samples of 20 leaf petioles per each replicate were taken from leaves opposite to cluster were used for the determination of $\mathrm{N}, \mathrm{P}$, and $\mathrm{K}$ content according to the methods described by Cottenie et al. (1982).

\section{Total proteins in the canes}

Total proteins were extracted in by Dure and Chlan (1981) and Oster et al. (1992). Protein content was determined spectro photometrically at 595nm according to Bradford (1976) and results were expressed as $\mathrm{g} / 100 \mathrm{~g}$ dry weight of the canes

\section{Yield}

At harvesting time when SSC \% of berries reached about 16-17\% in control, six clusters / vine were weighted and the average cluster weight was multiplied by number of clusters/vine to calculation average yield/vine.
Physical and Chemical properties

A sample of 6 clusters / vine was taken to determine:

- Average cluster weight (g) and average of 100 berry weight (g).

- Soluble solids content (SSC \%) was determined by using hand refractometer.

- Total acidity (g tartaric acid/ $100 \mathrm{ml}$ of juice) percentage was measured according to the methods described by A.O.A.C. (1980).

- Total phenols in the berries $(\mathrm{mg} / 100 \mathrm{~g}$ D.W) were determined according to the methods described by (Malick and Singh, 1980).

\section{Storage parameters at shelf life period}

Fruits form treatment were picked at harvest date and immediately taken to the laboratory to sort and picked in carton boxes ( $3 \mathrm{~kg}$ grapes each) three replicate of nine samples from every treatment were taken to be held at room temperature $\left(20-25^{\circ} \mathrm{C}\right.$ and $\left.50-70 \% \mathrm{RH}\right)$.

Samples were examined at 3 days interval to be objected the following determinations:

- Soluble solids content (SSC \%)

- Total acidity(g tartaric acid/ $100 \mathrm{ml}$ of juice)

- Cluster weight loss percentages Cluster weight loss $\%=$

$$
\frac{\text { Initial cluster }- \text { final cluster weight }}{\text { Initial clusters weight }} \times 100
$$

- Berry shatters percentages

$$
\text { Berries shattering } \%=\frac{\text { Weight of shatter }}{\text { Initial Cluster weight }} \times 100
$$

Berry decay

Berry decay $\%=\frac{\text { Weight of decayed berries }}{\text { Initial Cluster weight }} \times 100$

- Total loss in cluster weight percentages

Total loss in cluster weight percentage was calculated by adding the percentage of loss in cluster weight, berry shatter and decayed berries.

- Berry adherence strength $\mathrm{g} / \mathrm{cm}$ by using shatilons instrument .

\section{Statistical analysis}

The randomized complete blocks design was adopted for the experiment. The statistical analysis of the studying data was carried out according to Snedecor and Chocran (1980). Averages were compared using the Duncan's values at 5\% level. 


\section{Results and Discussion}

Shoot length, leaf surface area and total chlorophyll in the leaves

It is clear from the obtained data in Table 2 that spraying Thompson seedless grapevines with fulvic acid individually (T4) increased shoot length, leaf surface area, and total chlorophyll in leaves as compared with chitosan (T2) and salicylic acid (T3) respectively, in both seasons of study. The data also showed that the combination of chitosan + fulvic acid + salicylic acid (T8 ) recorded the highest significant values of shoot length $(170 \mathrm{~cm}$ and $178.3 \mathrm{~cm})$, leaf area (161 and $169 \mathrm{~cm}^{2}$ ) and total chlorophyll in leaves) 14.8 and $15.05 \mathrm{mg} / \mathrm{g}$ in leaves) as compared with control during both seasons. While, the control treatment (T1) recorded the lowest values (138.63 and $142 \mathrm{~cm}$ ) for shoot length, (137.3 and $\left.145.3 \mathrm{~cm}^{2}\right)$ for leaf area, (11.76 and $12.09 \mathrm{mg} / \mathrm{g}$ ) for total chlorophyll, in 2015 and 2016 respectively.

The data in Table 2 were in line with those reported by El-Boray et al. (2015) revealed that the treatment of fulvic acid induced indispensable positive effects for enhancing vegetative growth, total chlorophyll content, of Superior grapevines. Also, Maha (2016) showed that the total chlorophyll content was increased by salicylic acid spraying and there was a significant difference in total chlorophyll content associated with all treatments compared with the control. Furthermore, Shehata et al. (2012) found that using of chitosan recorded the highest vegetative growth parameters.

The beneficial effect of fulvic acid on shoot length, leaf area, and total chlorophyll in leaves could be to fulvic acid is effective because of its least molecular weight, it has necessary and capacity to readily bond minerals and elements into its molecular structure causing them resolve and be mobilized fulvic complexes, Fulvic acid usually loads carries 70 or more mineral and effect elements as bit of its molecular complexes, Aiken et al. (1985). Also, Chen et al. (2004) reported that fulvic acid are key ingredients of high quality foliar spray fertilizers. As they can help the penetration to the plant parts, stimulate the uptake of elements from plant surfaces into plant tissues. Hayat and Ahmad (2007) showed Salicylic acid is a phenolic phytohormone and is found in plants with roles in plant growth and improvement, photosynthesis, ion uptake and transport. Salicylic acid also stimulate specific modifications in leaf and chloroplast structure.
In addition, Salicylic acid is promote plant growth regulator of phenolic nature and classified as a improvement promoter and enhances plant force under biotic and abiotic stresses Hayat et al. (2010).

(Sheikha \& Al-Malki, 2011 and Farouk et al., 2012) indicated that treatment of chitosan significantly enhanced photosynthetic pigments concentration and activated the synthesis of carotenoids which protect chlorophyll from oxidation and enhanced chlorophyll content.

\section{$N, P, K(\%)$ content in leaf petioles and total protein in the canes}

The concerned data in Table 3 showed that spraying Thompson seedless grapevines with chitosan, salicylic acid and fulvic acid alone enhanced $\mathrm{N}$, $\mathrm{P}$, and $\mathrm{K}$ content in leaf petioles as compared with control. Moreover, the data showed that the combination of chitosan + salicylic acid + fulvic acid (T8) recorded the highest significant values of $\mathrm{N}, \mathrm{P}$, and $\mathrm{K}$ content in leaf petioles as compared with control during both seasons. The $\mathrm{N}$ values were $(2.02$ and $2.10 \%)$, the $\mathrm{P}$ values were $(0.57$ and $0.59 \%)$ and the $\mathrm{K}$ values were (1.66 and $1.69 \%$ ) during 2015 and 2016 seasons, respectively.

These results were in line with those by Abd ElHameed et al. (2014) showed that using the suitable $\mathrm{N}$ through 60 to $80 \%$ inorganic beside Fulvic acid was very effective in simulating percentages of $\mathrm{N}, \mathrm{P}$ and $\mathrm{K}$ in the leaves. The positive effect of fulvic acid could be containing percentage of potassium help improvement on nutritional status of the leaves especially potassium which reflected on enhancing vegetative growth. Rashid (1985) mentioned that fulvic acid not only has the ability to transport nutrients through cell membranes, but also sensitizes cell membranes and various physiological functions as well. Once applied to leaves, fulvic acids transport trace minerals directly to metabolic places within plant cells.

Maha (2016) found that applications containing salicylic acid improved that N, P and K of leaves. Also, Sarangthem and Singh (2003) reported that the foliar applications of salicylic acid enhanced the content of $\mathrm{N}, \mathrm{P}$ and $\mathrm{K}$ and nitrate reductive activity. Salicylic acid has been shown to regulate various aspects of vegetative growth and development, as well as play key signaling main in thermogenesis and disease resistance (Vlot et al., 2009). 
TABLE 2. Effect of Chitosan, salicylic acid and fulvic acid on Leaf area, shoot length and total chlorophyll in leaves of Thompson seedless grapevines during 2015 and 2016 seasons.

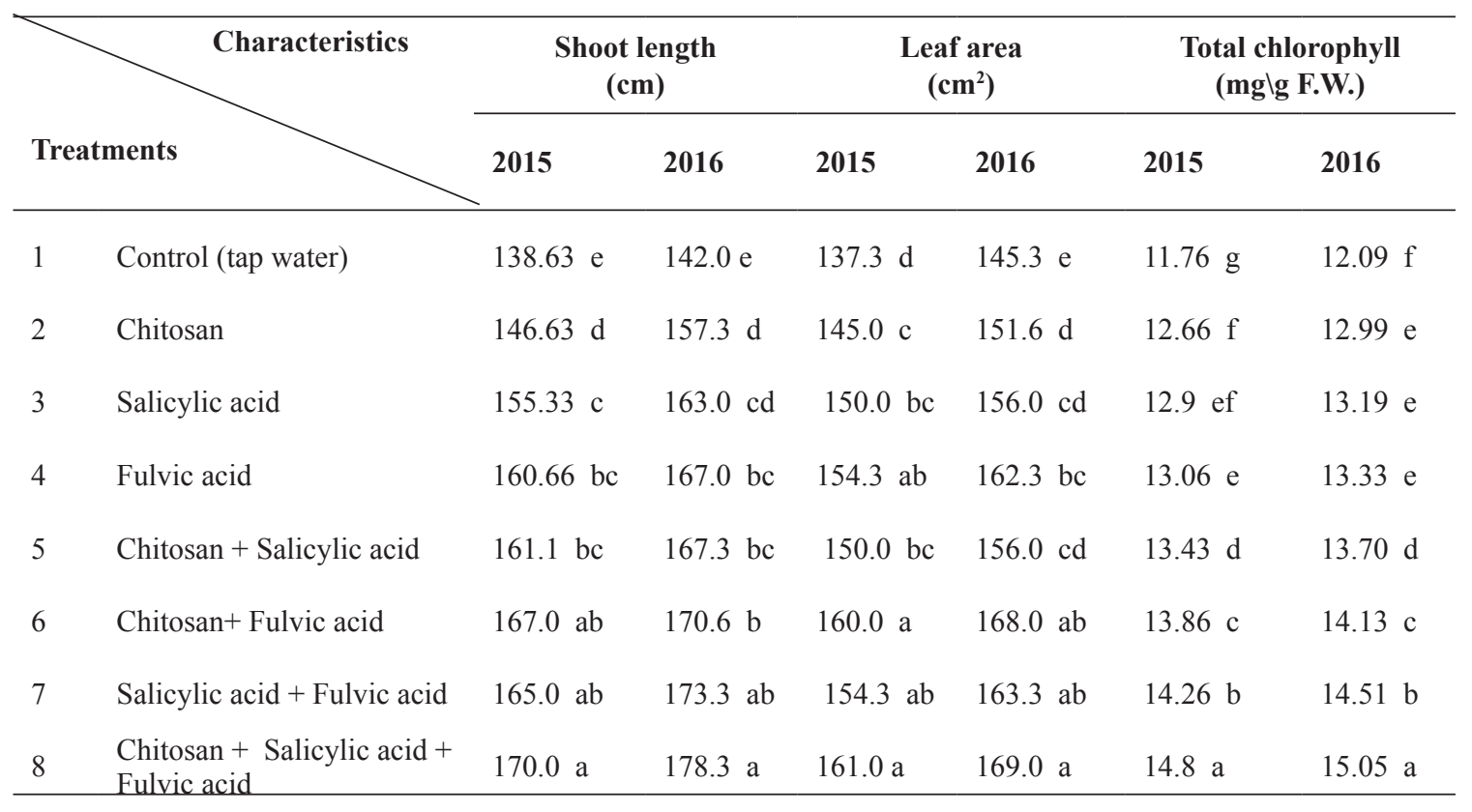

- In a column, figures having the same letter (s) are not significantly different.

TABLE 3. Effect of Chitosan, salicylic acid and fulvic acid on percentages of N, $P, K$ in leaf petioles and protein of Thompson seedless grapevines during 2015 and 2016 seasons

\begin{tabular}{|c|c|c|c|c|c|c|c|c|c|}
\hline & Characteristics & $\begin{array}{l}\text { Leaf } N \\
(\%)\end{array}$ & & $\begin{array}{l}\text { Leaf P } \\
(\%)\end{array}$ & & $\begin{array}{l}\text { Leaf K } \\
(\%)\end{array}$ & & $\begin{array}{l}\text { Protein } \\
(\%)\end{array}$ & \\
\hline & atments & 2015 & 2016 & 2015 & 2016 & 2015 & 2016 & 2015 & 2016 \\
\hline 1 & Control (tap water) & $1.21 \mathrm{~g}$ & $1.30 \mathrm{f}$ & $0.23 \mathrm{e}$ & $0.26 \mathrm{f}$ & $1.15 \mathrm{~g}$ & $1.2 \mathrm{f}$ & $14.53 \mathrm{e}$ & $15.06 \mathrm{~d}$ \\
\hline 2 & Chitosan & $1.28 \mathrm{fg}$ & $1.37 \mathrm{ef}$ & $0.28 \mathrm{e}$ & $0.31 \mathrm{ef}$ & $1.25 \mathrm{f}$ & $1.31 \mathrm{e}$ & $15.0 \mathrm{e}$ & $15.38 \mathrm{~d}$ \\
\hline 3 & Salicylic acid & $1.33 \mathrm{f}$ & $1.44 \mathrm{e}$ & $0.34 \mathrm{~d}$ & $0.36 \mathrm{de}$ & $1.31 \mathrm{e}$ & $1.34 \mathrm{e}$ & $16.1 \mathrm{~d}$ & $16.39 \mathrm{c}$ \\
\hline 4 & Fulvic acid & $1.48 \mathrm{e}$ & $1.59 \mathrm{~d}$ & $0.38 \mathrm{~cd}$ & $0.4 \mathrm{~cd}$ & $1.38 \mathrm{~d}$ & $1.42 \mathrm{~d}$ & $16.73 \mathrm{c}$ & $16.89 \mathrm{bc}$ \\
\hline 5 & $\begin{array}{l}\text { Chitosan + Salicylic } \\
\text { acid }\end{array}$ & $1.74 \mathrm{c}$ & $1.83 \mathrm{c}$ & $0.43 \mathrm{c}$ & $0.45 \mathrm{c}$ & $1.57 \mathrm{~b}$ & $1.61 \mathrm{~b}$ & $16.76 \mathrm{c}$ & $17.02 \mathrm{~b}$ \\
\hline 6 & Chitosan+ Fulvic acid & $1.88 \mathrm{~b}$ & $1.95 \mathrm{~b}$ & $0.49 \mathrm{~b}$ & $0.51 \mathrm{~b}$ & $1.61 \mathrm{ab}$ & $1.64 \mathrm{ab}$ & $17.5 \mathrm{~b}$ & $17.63 \mathrm{a}$ \\
\hline 7 & $\begin{array}{l}\text { Salicylic acid + Fulvic } \\
\text { acid }\end{array}$ & $1.63 \mathrm{~d}$ & $1.74 \mathrm{c}$ & $0.43 \mathrm{c}$ & $0.45 \mathrm{c}$ & $1.47 \mathrm{c}$ & $1.5 \mathrm{c}$ & $17.53 \mathrm{~b}$ & $17.64 \mathrm{a}$ \\
\hline 8 & $\begin{array}{l}\text { Chitosan+ Salicylic } \\
\text { acid + Fulvic acid }\end{array}$ & $2.02 \mathrm{a}$ & $2.09 \mathrm{a}$ & $0.57 \mathrm{a}$ & $0.59 \mathrm{a}$ & $1.66 \mathrm{a}$ & $1.69 \mathrm{a}$ & $18.1 \mathrm{a}$ & $18.21 \mathrm{a}$ \\
\hline
\end{tabular}

- In a column, figures having the same letter (s) are not significantly different. 
Also, the positive effect of chitosan increases vegetative growth and development which increased key enzymes activities of nitrogen metabolism (nitrate reductase and protease) and enhanced the transportation of nitrogen $(\mathrm{N})$ in the functional leaves which improved vegetative growth and development which reflected in enhancing growth and vine nutritional status (Gornik et al., 2008).

With respect to protein in the canes data in Table 3 revealed that all treatments used significant increased total protein in the canes as compared with control except chitosan (T2) gave non significant deference in total protein in the canes as compared with control during the two seasons of study. The combination of chitosan + fulvic acid + salicylic acid (T8) recorded the highest significant values of total protein in the canes (18.1 and $18.21 \mathrm{~g} / 100 \mathrm{~g} \mathrm{d.w})$ compared with control during both seasons. While, the control treatment (T1) gave the lowest values which recorded (14.53 and $15.06 \mathrm{~g} / 100 \mathrm{~g} \mathrm{~d} . \mathrm{w})$ in 2015 and 2016 seasons respectively,

These results are in accordance with those obtained by Trachevsky et al. (2011) mentioned that pea plants foliar sprayed with salicylic acid produced higher protein contents, Sarangthem and Singh (2003) proved that, the foliar application of salicylic acid increased the level of proteins. Jackson (1993) mentioned that Fulvic acid increased metabolism of proteins, DNA/ RNA, and Enzymes. Chitosan enhanced protein which reflected resistance role the defense against diseases (Iriti and Faoro, 2009).

\section{Yield, cluster weight, 100 berries weight and total phenols in berries}

Data in Table 4 obviously revealed that spraying Thompson seedless grapevines three times with Chitosan (T2), salicylic acid (T3) and fulvic acid alone (T4) improving yield, cluster weight and berry weight as compared with control and gave non significant deference between of them in this respect. Also, the combined application of chitosan + fulvic acid + salicylic acid (T8 ) recorded the highest significant values of yield per vine $(10.08 \& 10.15 \mathrm{~kg} /$ vine $)$ cluster weight $(560.33 \& 577 \mathrm{~g})$ and 100 berries weight (255 \&266g) followed in a descending order by the treatment of salicylic acid + fulvic acid (T7) which recorded the values of yield per vine (9.83\& $10.15 \mathrm{~kg} / \mathrm{vine})$, cluster weight $(552.3 \&$
$565.66 \mathrm{~g}) 100$ berry weight (240 \&258.66 g) as compared with control during both seasons. While, the control treatment (T1) gave the lowest values which recorded yield per vine $(8.75 \& 8.85$ $\mathrm{kg} / \mathrm{vine}$ ), cluster weight (525 \& 531.33g (and berry weight (226.6 \& 231g) in 2015 and 2016 seasons respectively,

These results are in agreement with those reported on El-Boray et al (2015) revealed that foliar spray fulvic acid promoted irreplaceable positive effects for enhancing yield, physical characteristics of cluster and berries of Superior grapevines. Chen et al. (2004) showed that fulvic acid material have different effects on plants appeared evidence of stimulation on plant develops by humic substances and consequently gave the highest values of yield by acting on mechanisms involved in: respiration, photosynthesis, protein synthesis, water, and nutrient uptake. Marzouk and Kassem (2011) and Ahmed et al. (2015) found that Cluster and berry weight as well as vine yield were improved by all sprayed chemicals, especially, salicylic acid . It is an important secondary metabolite in grape berries and plays an essential role in determining berry quality such as colour, berry size and bitterness Chamkha et al. (2003). Also, Sabreen et al. (2015) reported that the interaction applications between $\mathrm{N}$ at $75 \mathrm{~kg} /$ feddan and treatment plants with chitosan at $0.10 \mathrm{~g} / 1$ gave the highest values of yield in summer squash fruits.

The increment in yield per vine and physical Characteristics of berries could be attribute to enhancing effect on berry weight as result of enhancing the nutritional status of the vines (Table 3) and enhancing leaf surface area and total chlorophyll in leaves (Table 2) as result using Chitosan + Fulvic acid + Salicylic.

Regarding total phenols in berries data in Table 4 showed that spraying grapevines three times with salicylic acid alone (T3) significantly increased total phenols in berries compared with fulvic acid (T4) and chitosan (T2) during both seasons. Also, the combination of Chitosan + fulvic acid + salicylic acid (T8) recorded the highest significant values of total phenols in berries) 90.66 and 91.67 $\mathrm{mg} / 100 \mathrm{~g}$ d.w (as compared with other treatments during both seasons. On the other hand, the control treatment (T1) gave the lowest values of total phenols in berries which recorded (65.60 and $67.58 \mathrm{mg} / 100 \mathrm{~g} \mathrm{~d} . \mathrm{w})$ in 2015 and 2016 seasons, respectively 
These results are in harmony with those reported by Maha (2016) who found that treatments containing salicylic acid improvement a total phenols. In addition, Ranjbaran et al. (2011) and Champa et al. (2015) found that salicylic acid treatment also enhanced total phenolic content of berries after the shelf life period .Pan and Liu (2011) reported that Chemical elicitors, such as chitosan increase total phenolicsa and flavonoids after post-harvest treatment in mangos .Phenolic compounds are the almost berry quality for grapes and their yield since they confer to berry color and organoleptic properties such as flavor, soreness, and astringency, also. in addition to the aforesaid role as antioxidants Gomez-Cordoves and Gonzalez-Sanjose (1995).

\section{Storage parameters at shelf life period SSC \% and acidity \% on berries}

Data in Table 5 clearly indicated that spraying Thompson seedless grapevines three times with chitosan, fulvic acid and salicylic acid either single or combination of them increased SSC \% and reduced acidity $\%$ as compared with control during shelf life period in both seasons of study. In addition, treating the vines with chitosan individually (T2) enhanced SSC \% and decreased acidity \% compared with fulvic acid (T4) and salicylic acid (T3) after storage 9 days at shelf life in both seasons of study. Also, the data showed that the combination of chitosan + fulvic acid + salicylic acid (T8) gave in both seasons not only the highest significantly values in SSC) 21.8 and $22.8 \%$ (but also, the lowest total acidity $(0.37$ and $0.35 \%$ ) after storage 9 days at shelf life as compared with other treatments during shelf life period in both seasons of study. While, the control treatment (T1) gave the lowest values of SSC \% which recorded (20.13 and $20.3 \%)$ and gave the highest values of total acidity (0.59 and $0.58 \%)$ after storage 9 days at shelf life in 2015 and 2016 seasons, respectively

These results are in line with those reported by Meng et al (2008) and Ghasemnezhad et al (2013) they found chitosan increase in total soluble solids (TSS) and decreased titratable acidity during storage.

The beneficial affect of chitosan, fulvic acid and salicylic on enhancing chemical properties of the berries may be interpreted to its role in achieving a good balance between vegetative growth and fruiting through nutrients availability which is reflected its turn on increasing the accumulation of total carbohydrate and resulting the stimulation of ripening. Li et al. (1999) and Champa et al. (2015).

TABLE 4. Effect of Chitosan, salicylic acid and fulvic acid on yield, cluster weight, berry weight and total phenols in berries of Thompson seedless grapevines during 2015 and 2016 seasons.

\begin{tabular}{|c|c|c|c|c|c|c|c|c|c|}
\hline & Characteristics & $\begin{array}{r}\mathrm{Yi} \\
(\mathrm{Kg}\end{array}$ & $\begin{array}{l}\text { ld } \\
\text { vine) }\end{array}$ & $\begin{array}{r}\text { Cluster } \\
(\mathrm{g}\end{array}$ & weight & 100 ber & weight & $\begin{array}{l}\text { Total } \\
(\mathrm{mg} / 1 \mathrm{10}\end{array}$ & $\begin{array}{l}\text { henols } \\
\text { g D.W) }\end{array}$ \\
\hline & & 2015 & 2016 & 2015 & 2016 & 2015 & 2016 & 2015 & 2016 \\
\hline 1 & Control (tap water) & $8.75 \mathrm{c}$ & $8.85 \mathrm{~d}$ & $525.0 \mathrm{e}$ & $531.3 \mathrm{e}$ & $226.6 \mathrm{e}$ & $231.0 \mathrm{f}$ & $65.60 \mathrm{~g}$ & $67.58 \mathrm{~g}$ \\
\hline 2 & Chitosan & $9.46 \mathrm{~b}$ & $9.56 \mathrm{bc}$ & $531.3 \mathrm{de}$ & $540.3 \mathrm{~d}$ & $236.6 \mathrm{~cd}$ & $245.0 \mathrm{de}$ & $73.73 \mathrm{e}$ & $75.43 \mathrm{e}$ \\
\hline 3 & Salicylic acid & $9.32 \mathrm{~b}$ & $9.52 \mathrm{c}$ & $528.7 \mathrm{de}$ & $538.7 \mathrm{de}$ & $230.0 \mathrm{de}$ & $241.0 \mathrm{e}$ & $82.63 \mathrm{~d}$ & $83.68 \mathrm{~d}$ \\
\hline 4 & Fulvic acid & $9.45 \mathrm{~b}$ & $9.45 \mathrm{c}$ & $535.3 \mathrm{~cd}$ & $547.0 \mathrm{~cd}$ & $236.3 \mathrm{~cd}$ & $247.3 \mathrm{~cd}$ & $70.37 \mathrm{f}$ & $72.08 \mathrm{f}$ \\
\hline 5 & $\begin{array}{l}\text { Chitosan }+ \text { Salicylic } \\
\text { acid }\end{array}$ & $9.61 \mathrm{~b}$ & $9.71 \mathrm{abc}$ & $540.0 \mathrm{c}$ & $550.0 \mathrm{c}$ & $237.0 \mathrm{~cd}$ & $251.7 \mathrm{c}$ & $87.58 \mathrm{~b}$ & $88.24 \mathrm{~b}$ \\
\hline 6 & Chitosan+ Fulvic acid & $9.76 \mathrm{ab}$ & $9.89 \mathrm{ab}$ & $550.0 \mathrm{~b}$ & $553.5 \mathrm{c}$ & $247.6 \mathrm{ab}$ & $258.7 \mathrm{~b}$ & $75.2 \mathrm{e}$ & $76.99 \mathrm{e}$ \\
\hline 7 & $\begin{array}{l}\text { Salicylic acid }+ \\
\text { Fulvic acid }\end{array}$ & $9.83 \mathrm{ab}$ & $9.97 \mathrm{ab}$ & $552.3 \mathrm{~b}$ & $565.7 \mathrm{~b}$ & $240.0 \mathrm{bc}$ & $258.7 \mathrm{~b}$ & $84.45 \mathrm{c}$ & $85.47 \mathrm{c}$ \\
\hline 8 & $\begin{array}{l}\text { Chitosan+ Salicylic } \\
\text { acid + Fulvic acid }\end{array}$ & $10.08 \mathrm{a}$ & $10.15 \mathrm{a}$ & $560.33 \mathrm{a}$ & $577.0 \mathrm{a}$ & $255.0 \mathrm{a}$ & $266.0 \mathrm{a}$ & $90.66 \mathrm{a}$ & $91.67 \mathrm{a}$ \\
\hline
\end{tabular}




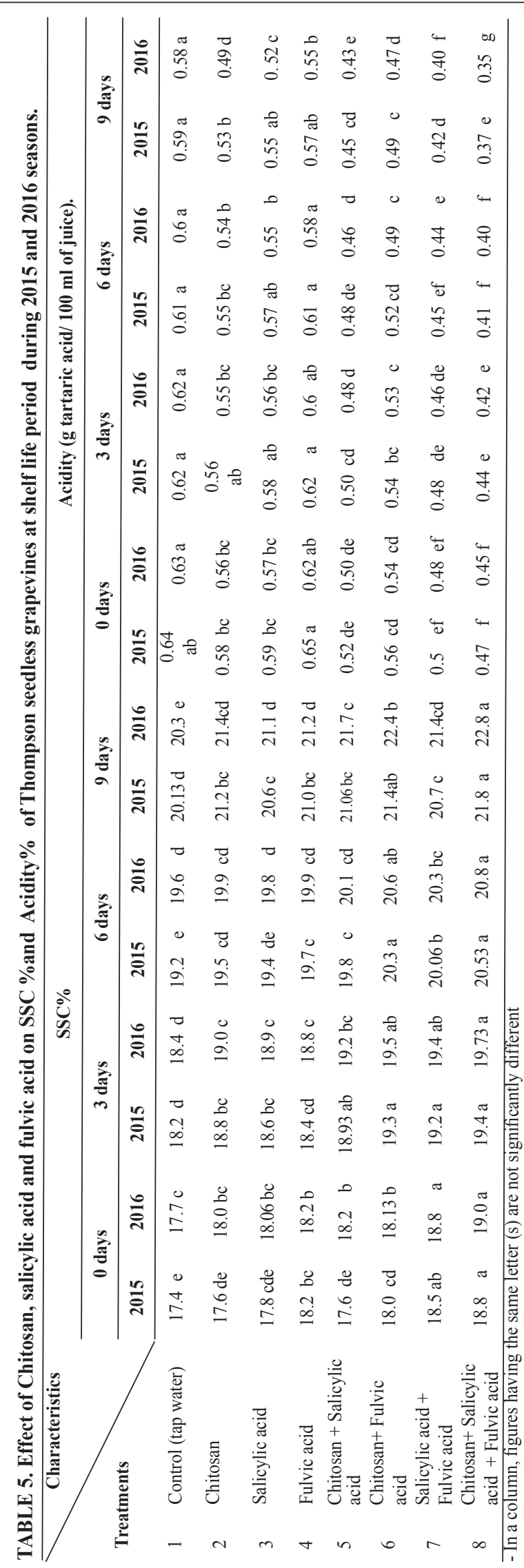

Cluster weight loss, berry shatter and berry decay percentages.

Data in Table 6 clearly show that spraying Thompson seedless grapevines three times with chitosan, fulvic acid and salicylic acid either single or combination of them significantly gave the lowest values of cluster weight loss $\%$, berry shatter $\%$ and berry decay $\%$ compared with control during shelf life period in both seasons of study. Also, the combination of chitosan + fulvic acid + salicylic acid (T8) gave the lowest values of cluster weight loss (19 and $18.32 \%$ ) berry shatter percentages (5.88 and $5.75 \%)$ and berry decay (6.17 and $5.95 \%$ ) after storage 9 days at shelf life as compared with other treatments during in 2015 and 2016 seasons of study. While, the control treatment (T1) gave the highest values in cluster weight loss $\%$ (22.5 and 22\% ), berry shatter (7.05 and $7.02 \%)$ and berry decay (8.80 and $8.56 \%$ ) percentages after storage 9 days at shelf life in 2015 and 2016 seasons of study, respectively.

The beneficial affect of chitosan on decreasing weight loss, berry decay and berry shatter may be the covering offers a protective barrier against bacterial contamination and moisture transfer to extend the shelf life. Other researchers mentioned that chitosan coatings help to reduce transpiration and control weight loss to retard ripening and extend shelf life by controlling respiration average and ethylene production Jiang and Li, (2001).

These results were in line by Romanazzi (2010) reported that application of chitosan covering inhibited respiration average of grapes varieties and strawberries. Also, Chitosan covering on fresh berries can expand modified atmosphere storage and reduce quality changes through control of the internal gas composition of the fruits.

Also, Zheng et al. (2003) showed that salicylic acid as produces free radical which bans normal respiration and salicylic acid can also reduce respiration average and berry weight loss by stoma closing. Champa et al. (2015) found that reducing the rate of berry softening reduced, decay incidence and enzymatic activity of pectin and membrane electrolyte leakage.

Bassem (2015) showed that salicylic acid applications at different concentrations were significantly effective in reducing weight loss, berry decay and berry shatter during cold storage 
period and shelf life as compared to the control. In addition, Ranjbaran et al. (2011) found that the lowest berry shatter was observed in all of the salicylic acid -treated clusters .Champa et al. (2015) showed that salicylic acid increased berry size and reducing the rate of Cluster weight loss, berry shatter percentages and berry decay

Total loss in cluster weight percentages and berry adherence strength

It is clear in Table 7 that spraying Thompson seedless grapevines three times with chitosan, fulvic acid and salicylic acid either single or combination of them significantly lowest total loss in cluster weight as compared with control during shelf life period in both seasons of study.

The combination of chitosan + fulvic acid + salicylic acid (T8) gave the lowest values of total loss in cluster weight (31.05and30.02 after storage 9 days at shelf life) as compared with other treatments during shelf life period in both seasons of study.

These results are on the same line by Chien et al. (2007) mentioned that chitosan covering has been found to be a beneficial part of a strategy to decrease the weight loss due to by pathogen isolates that are resistant to currently used postharvest fungicides. Also, Shiri et al (2013) reported that chitosan coatings help to reduce transpiration and control weight loss \% and slow down ripening and extend shelf life by controlling respiration rate and ethylene production.

Wafaa et al. (2014) mentioned that the present data reveal that $1 \%$ chitosan recorded the lowest significant percentage of fruit weight loss in both seasons Also, Alijo et al. (2015) showed that salicylic acid had significant effect on quality parameters of peach fruits cv. 'Elberta' during of storage period.

Salicylic acid can reduce respiration through inhibition of ethylene biosynthesis or action (Srivastava and Dwivedi, 2000). Salicylic acid also cause decrease respiration rate and fruit weight loss by closing stomata. Further, a potential postharvest using preserves fruit quality is the use of surface coatings. They are usually applied for fresh berries to provide alternative modified atmosphere storage by decreasing quality changes and quantity losses through modification and control of the internal atmosphere of the singular individual fruits Park (1999).

With respect to berry adherence strength data in Table 7 revealed that berry adherence strength significant increase when applied different spraying grapevines with chitosan, fulvic acid and salicylic acid as compared with control during shelf life period the two seasons of study.

Also, the combination of chitosan + fulvic acid + salicylic acid (T8) significantly recorded the highest values of berry adherence strength (265 and $269.6 \mathrm{gm} / \mathrm{cm}$ after storage 9 days at shelf life) compared with other treatments during both seasons. While, the control treatment (T1) gave the lowest values of berry adherence strength (148.3 and $150.6 \mathrm{gm} / \mathrm{cm}$ after storage 9 days at shelf life), in both seasons, respectively.

These results are in agreement with those reported by Marzouk and Kassem (2011) found that Berry adherence strength increased and the percentage of unmarketable berries decreased by all sprayed compounds especially, salicylic acid, except ethylene . In addition, Wafaa et al. (2014) found that treated $1 \%$ chitosan gave the highest significant berry adherence compared with the other treatments. Champa et al. (2015) mentioned that salicylic acid improved berry physicochemical properties at harvest and extended the postharvest life of table grape cv. Flame Seedless

Also, Nevine, Taha and El-Ghany (2016) found that Calbor and Inca + Humic acid application decreased less total loss weight for 9 weeks, while Humic acid and CPPU + Calbor application caused less fruit weight loss for 6 weeks of storage.

\section{The economic study}

It is clear from the obtained data in Table 8 that spraying chitosan, fulvic acid and salicylic acid either alone or in combination of them gave the best net profit/ feddan as compared with control. Also, the fulvic acid (T4) individually gave the highest net profit/ feddan as compared with chitosan (T2) and salicylic acid (T3). In addition, the treatment of salicylic acid + fulvic acid (T7) gave the highest values in net profit/feddan as compared with other treatments which recorded 3180 (L. E.) over control as average two seasons. 


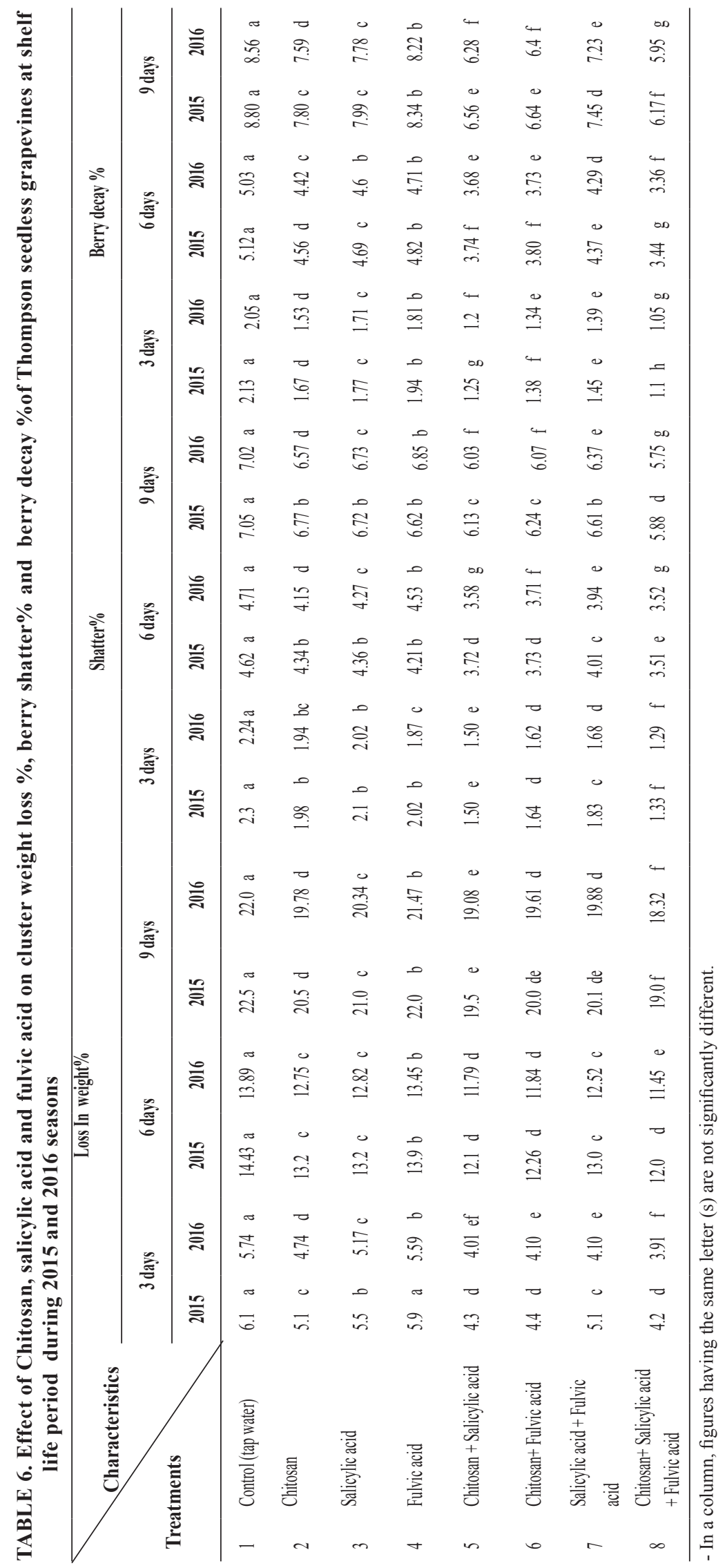

Egypt. J. Hort. Vol. 44, No. 1 (2017) 


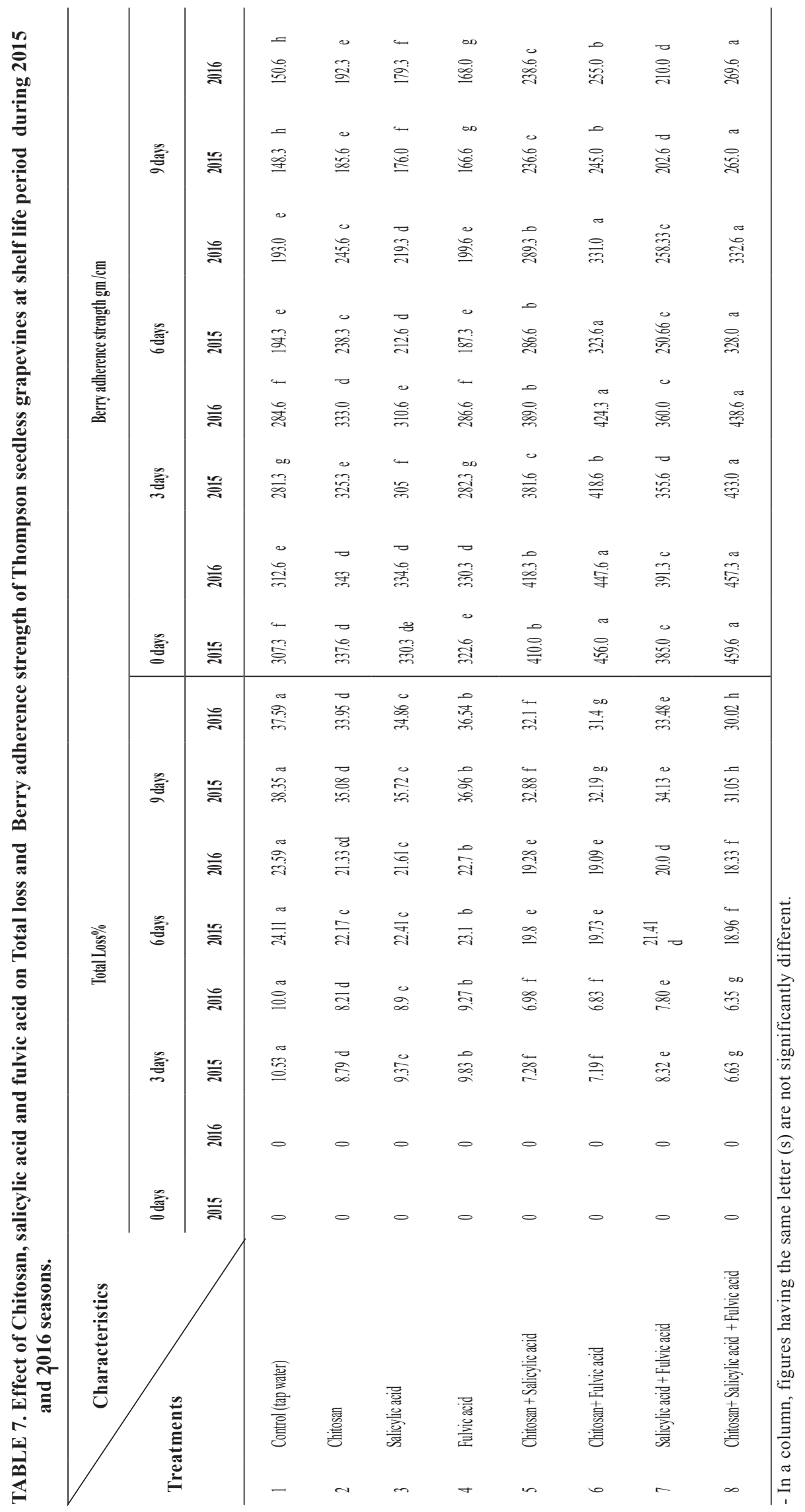

Egypt. J. Hort. Vol. 44, No. 1 (2017) 
TABLE 8. Economic study on costs and net profit /feddan of Chitosan, salicylic acid and fulvic acid of Thompson seedless grapevines as average for two seasons 2015 and 2016 seasons.

\begin{tabular}{|c|c|c|c|c|c|c|c|c|}
\hline & Treatments & $\begin{array}{c}\text { Costs of } \\
\text { *cultural } \\
\text { practices } \\
\text { / fed. } \\
\text { (L.E.) }\end{array}$ & $\begin{array}{l}\text { Treatments } \\
\text { costs / fed. } \\
\text { (L.E.) }\end{array}$ & $\begin{array}{l}\text { Total } \\
\text { costs / } \\
\text { fed. } \\
\text { (L.E.) }\end{array}$ & $\begin{array}{l}\text { Yield/ } \\
\text { fed. } \\
\text { Kg }\end{array}$ & $\begin{array}{c}\text { Total } \\
\text { production } \\
\text { / fed. } \\
\text { (L.E.) }\end{array}$ & $\begin{array}{c}\text { Net } \\
\text { profit / } \\
\text { fed. } \\
\text { (L.E.) }\end{array}$ & $\begin{array}{l}\text { Net profit / } \\
\text { fed. over } \\
\text { control } \\
\text { (L.E.) }\end{array}$ \\
\hline 1 & $\begin{array}{c}\text { Control } \\
\text { (tap water) }\end{array}$ & 7200 & 0 & 7200 & 8800 & 26400 & 19200 & 0 \\
\hline 2 & Chitosan & 7200 & 840 & 8040 & 9450 & 28350 & 20310 & 1110 \\
\hline 3 & Salicylic acid & 7200 & 90 & 7290 & 9420 & 28260 & 20970 & 1770 \\
\hline 4 & Fulvic acid & 7200 & 30 & 7230 & 9510 & 28530 & 21300 & 2100 \\
\hline 6 & $\begin{array}{c}\text { Chitosan }+ \\
\text { Salicylic acid }\end{array}$ & 7200 & 930 & 8130 & 9660 & 28980 & 20850 & 1650 \\
\hline 5 & $\begin{array}{c}\text { Chitosan+ Fulvic } \\
\text { acid }\end{array}$ & 7200 & 870 & 8070 & 9825 & 29475 & 21405 & 2205 \\
\hline 7 & $\begin{array}{l}\text { Salicylic acid }+ \\
\text { Fulvic acid }\end{array}$ & 7200 & 120 & 7320 & 9900 & 29700 & 22380 & 3180 \\
\hline 8 & $\begin{array}{c}\text { Chitosan+ } \\
\text { Salicylic acid }+ \\
\text { Fulvic acid } \\
\end{array}$ & 7200 & 960 & 8160 & 10115 & 30345 & 22185 & 2985 \\
\hline
\end{tabular}

Cultural practices such as (Fertilizers, Pesticides, fungicides, Irrigation and Labour)

- Chitosan (g) $200 \times 3$ doses $=600 \mathrm{~g}=840$ (L.E.) $/$ feddan

- Salicylic acid g) $200 \times 3$ doses $=450 \mathrm{~g}=90$ (L.E.) $/$ feddan

- Fulvic acid $(\mathrm{g}) \quad 500 \times 3$ doses $=1500 \mathrm{~g}=30$ (L.E.) $/$ feddan

- One feddan $=1000$ vines

- Price $/ 1 \mathrm{~kg}$ from Yield = 3 (L.E.)

\section{Conclusion}

The best results under condition of this study with regard to vegetative growth, yield, fruit quality and net profit /feddan of Thompson seedless grapevines were obtained when the vines were spraying with salicylic acid + fulvic acid (T7) and chitosan + fulvic acid + salicylic acid (T8) at rate $(500 \mathrm{ppm})$ three times at growth start, one week after fruit set and at veraison

\section{References}

A.O.A.C. (1980) "Association of Official Analytical Chemists", 14th ed., published by A.O.A.C., Washington D.C., USA.

Abd El-Rahman, M.M.A. and El-Masry, S.M.A (2012) Response of Valencia trees to foliar application of some vitamins, salicylic acid and turmeric extract, Minia J. Agric. Res. Dev., 32 (5), 851-867.
Abd El-Hameed, M.M.W., Ali, A.G., Esis A. R. and Ahmed, R.M. (2014) Reducing mineral $\mathrm{N}$ fertilizer partially in Thompson seedless vineyards by using fulvic acid and effective microorganisms. World Rural Obser, 6 (4), $36-42$.

Adwiger, L.A. (2013) "Multiple effects of chitosan on plant systems: Solid science or hype". Plant Science, 208, 42-9.

Ahmed, F.F., Hamdy I.M.I. and Moustafa M.H.A. (2015) Response of Sakkoti Date Palms to Spraying Salicylic Acid. World Rural Observations, 7 (1), 119-125.

Ahmed, E.F.S (2011) Response of Sakkoti date palms to foliar application of salicylic acid. Minia J. Res. Dev., 21 (2), 305-316. 
Ahmed, F.F., Kamel, M.Kh. and Ibrahim, H.LM. (2014) The synergistic effect of using plant extracts and salicylic acid on yield and fruit quality of Keitte mango trees. Stem Cell, 5 (2), 30-39.

Aiken, G.R., McKnight, D.M. (1985) Humic Substances in Soil, Sediment, and Water. Geochemistry, Isolation, and Characterization. New York, John Wiley \& Sons.

Alijo B.O., Vahid, A. and Vahid, Z. (2015) The Effects of Postharvest Treatments of Salicylic Acid and Cinnamon Oil on The Storage Of Peach Bull. Env. Pharmacol. Life Sci., 4 (4), 145-149.

Bassem N.S. (2015) Impact of postharvest salicylic acid and jasmonic acid treatments on quality of "Crimson Seedless" grapes during cold storage and shelf life. International Journal of Advanced Research, 3 (5), 483-490.

Bradford, M.M. (1976) A rapid and sensitive method for quantitation of microgram quantities of protein utilizing the principle of protein dyebinding Analytical Biochemistry pp 72, 248

Chamkha, M., Cathala B., Cheynier .V and Douillard R. (2003) Phenolic composition of champagnes from Chardonnay and Pinot Noir vintages. J. Agr. Food Chem., 51, 3179-3184. doi: 10.1021/ jf021105j.

Champa, W. A. Harindra, M. I. S. Gill., B. V. C. Mahajan and N. K. Arora (2015) Preharvest salicylic acid treatments to improve quality and postharvest life of table grapes (Vitis vinifera L.) cv. Flame Seedless . J Food Sci Technol. 2015 Jun, 52(6), 3607-3616.

Chen, Y., M. De Nobili and T. Avid (2004) Stimulatory effects of humic substances on plant growth. In: F. MAGDOFF, R. R. WEIL (Eds.): Soil Organic Matter in Sustainable Agriculture, 103-129 CRC Press, New York, USA.

Chien, P.J., Sheu , F. and Lin, H.R. (2007) Coating citrus (Murcott tangor fruit with low molecular weight chitosan increases postharvest quality and shelf life. Food Chem 100, 1160-1164

Cottenie, A., Verloo, M., Kiekens, L., Relgho, G. and Camerlynuck, W. (1982) Chemical analysis of plant and soil. Lab. of analytical and Agro chemistry State Univ. Gent, Belgium.

Dure, I. I. and Chlan, C. (1981) Developmental bio- chemistry of cotton seed embryogenesis and germination XII. Purification and properties of principle storage protein. Plant Physiol., 68, 180.
El-Borai, M.S., M.F. Mostafa, A.D. Shaltout and K.H. Hassan (2015) Influnce fulvic acid plus some micro elements and microrganisms On yield and quality of characteristics Superior grapevines. J. P. Lant. Production, Mansoura Univ., 6 (3), 287 -305

Farouk, S. and A. Ramadan Amany (2012) Improving growth and yield of cowpea plant by foliar application of chitosan under water stress. Egyptian Journal of Biology., 7, 14-26.

Ghasemnezhad. M., Zareh. S, Rassa, M and HassanSajedi R. ( 2013) Effect of chitosan coating on maintenance of aril quality, microbial population and PPO activity of pomegranate (Punica granatum L. cv. Tarom) at cold storage temperature. J. Sci. Food Agric., 93, 368-374.

Gomez-Cordoves, M.C. and M.L. Gonzalez-Sanjose (1995) Interpretation of color variables during the aging of red wines: relationship with families of phenolic compounds. Journal of Agriculture and Food Chemistry, 43, 557-561.

Gornik, K., Grzesik, M. and Duda, B.R. (2008) The effect of chitosan on rooting of gravevine cuttings and on subsequent plant growth under drought and temperature stress. J. Fruit Ornamental Plant Res 16, 333-343

Hayat, Q., Hayat, S., Irfan, M. and Ahmad, A. (2010) Effect of exogenous salicylic acid under changing environment: A review. Environ. Exp. Bot., 68, 14-25.

Hayat, S. and Ahmad, A. (2007) Salicylic acid - A Plant Hormone, Springer. ISBN 1-4020-5183-2.

Iriti, M and Faoro, F. (2009) Chitosan as a MAMP, searching for a PRR. Plant Signaling and Behaviour, 4, 66-68.

Jackson, W.R. (1993) Humic, Fulvic and Microbial Balance: Organic Soil Conditioning, 569-570. Evergreen, Colorado: Jackson Research Center.

Jiang, Y and Li, Y. (2001) Effects of chitosan coating on postharvest life and quality of longan fruit. Food Chemistry, 73, 139-143.

Li, N., Wang, X. and Lu, B.L. (1999) Study of the effect of apple liquid fertilizes on the growth and fruit development of starkrimson apple variety. China Fruits, 4, 20-21. (C.F. Hort. Abst., 70S: 3628).

Mackinny, G. (1941) Absorption of light by chlorophyll soluation. J. Bio. Chem., 140, 315-322.

Maha, M. Abdel-Salam (2016) Effect of Foliar Application of Salicylic Acid and Micronutrients on the Berries Quality of "Bez El Naka" Local Grape Cultivar. Middle East J. Appl. Sci., 6 (1), 178 - 188.

Egypt. J. Hort. Vol. 44, No. 1 (2017) 
Malik, C.P. and Singh, M.B. (1980) Plant Enzymology and Histo Enzymology. Kalyani Publishers, New Delhi, p.28.

Marzouk, H.A .and Kassem, H.A. (2011) Improving yield, quality and shelf life of Thompson seedless grapevine by preharvest foliar applications. Sci. Hortic., 130, 425-430.

Meng, X.H., Tian, S.P., Li, B.Q and Liu, J. (2008) Physiologic responses and quality attributes of table grape fruit to chitosan preharvest spray and postharvest coating during storage. Food Chemistry, 106, 501-508.

Montero, F.J., De Juan, J.A., Cuesta, A. and Brasa, A. (2000) Non-destructive methods to estimated leaf area in (Vitis vinifera L.). Hort. Sci., 35, 696 - 698.

Nevine, M. and El-Ghany, K.M. (2016) Some horticultural and pathological studies to reduce fruit decay of" Anna" apple and increase fruit set,yield and improve fruit quality and storability. Journal of American Science, 12 (1), 104-122

Oster, V., Kardinal, C., Brghardt, H., Lottspeich, F. and Rudiger, W. (1992) Natural inhibitors of germination and growth. VI. Detection of a carboxyterminal fragment of the heat shock protein HSP70 after coumarin treatment. J. Plant Physiol., 40, $110-115$.

Pan, Y.G. and Liu, X.H. (2011) Effect of benzothiadiazole-7-carbothioic acid S-methyl ester (BTH) treatment on the resistant substance in postharvest mango fruits of different varieties. Afr. J. Biotechnol., 10, 15521-15528

Park, H.J (1999) Development of advanced edible coatings for fruits. Trends Food Sci Technol., 10, 254-260.

Ranjbaran, E., Sarikhani, H., Wakana, A. and Bakhshi, D. (2011) Effect of salicylic acid on storage life and postharvest quality of grape (Vitis vinifera L.cv. BidanehSefid). J. Fac. Agr., Kyushu Univ., 56 (2), 263-269.

Rashid, M.A. (1985) Geochemistry of Marine Humic Substances. New York: Springer-Verlag

Romanazzi, G. (2010) Chitosan treatment for the control of postharvest decay of table grapes, strawberries and sweet cherries. Fresh Produce, 4, 111-115.

Sabreen, Kh. Ibraheim, A. and Mohsen, A.A.M. (2015) Effect of Chitosan and Nitrogen Rates on Growth and Productivity of Summer Squash Plants. Middle East Journal of Agriculture Research, 4 (4), 673681

Egypt. J. Hort. Vol. 44, No. 1 (2017)
Sarangthem, K. and, Singh, T.H.N. (2003) Efficacy of salicylic acid on growth, nitrogen metabolism and flowering of Phaseolus vulgaris. Crop Res., 26, 355-360.

Sheikha, S.A., and Al-Malki, F.M. (2011) Growth and chlorophyll responses of bean plants to the chitosan applications. European Journal of Scientific Research, 50 (1), 124 - 134.

Shehata, S.A., Fawzy, Z.F. and El-Ramady, H.R. (2012) Response of cucumber plants to foliar application of chitosan and yeast under greenhouse conditions Aust. J. Basic Appl. Sci., 6 (4), 63-71.

Shiri, M.A., Bakhsh, D.M., Ghasemnezhad, M., Dadi, A., Papchatzis, M. and Kalorizou, H. (2013) Chitosan coating improves the shelf life and postharvest quality of table grape (Vitis vinifera ) cultivar Shahroudi. Turk. J. Agric. For., 37, 148-156

Snedecor, G.W. and Cochran,W.G. (1980) "Statistical Methods", 7th ed., The Iowa State Univ. Press. Amers. , Iowa, U.S.A., 593 p.

Srivastava, M.K and Dwivedi, U.N. (2000) Delayed ripening of banana fruit by salicylic acid. 158, 87- 96 .

Tarchevsky, I.A., Yakovelva, V.G. and Egorova, A.M. (2011) Effects of salicylic acid on protein content and $14 \mathrm{c}$ amino acid incorporation in to proteins of pea roots. Russian Journal of Plant Physiology, 580-588.

Vlot, A.C., Dempsey, D.A. and Klessig, D.F (2009) Salicylic Acid, a Multifaceted Hormone to Combat Disease. Annual Review of Phytopathology, 47, 177-206.

Wafaa, A., Abd Elwahab, S., Abd Elwahab, M. and Kamel, O.T. (2014) Using Safe Alternatives for Controlling Postharvest Decay, Maintaining Quality of Crimson Seedless Grape. World Appl. Sci. J., 31 (7), 1345-1357.

Zhang, Y., Chen, K., Zhang, S. and Ferguson, I. (2003) The role of salicylic acid in postharvest ripening of kiwifruit, Postharvest Biol. Technol., 28 (1), 67-74

(Received 15/5/2017; accepted 16/7/2017) 


\title{
تأثير الثيّتوزان وحمض السالسيلك وحمض الفولفيك على النمو الخضرى والمحصول

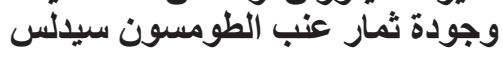

\author{
مسعد عوض القناوى \\ قسم بحوث العنب ـ معهد بحوث البساتين ـ مركز البحوث الزر اعبه ـ القاهرة ـ مصر.
}

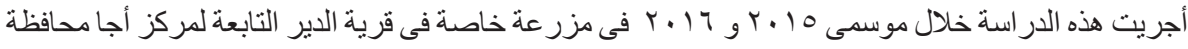

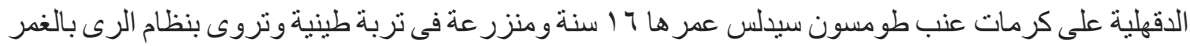

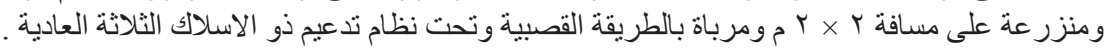

وذلك بهدف دراسة تأثثير الرش ببعض المركبات مثل الثينوزان و السالسيلك و الفولفيك بصورة منفردة

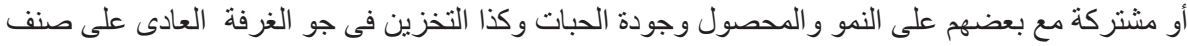

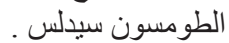

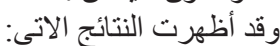

ـ أن الاستخدام الفردي للمركبات مثل (الشيتوز النيان و السالسيلك و الفولفيك) بصورة منفردة أو رشها مجتمعة كان

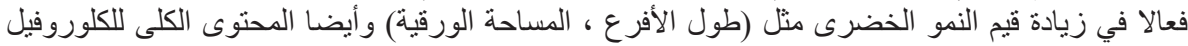

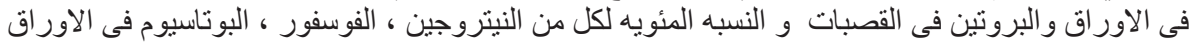

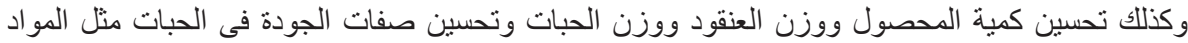

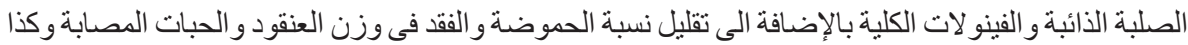

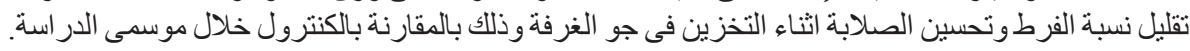

- وكانت المعاملات المشتركة من الثيتوز ان و السلسيلك و الفولفيك أفضل حالا من استخدامهم منفردين فى هذا الصدد.

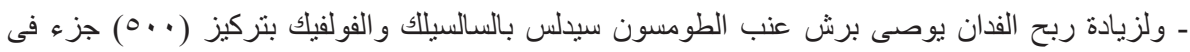

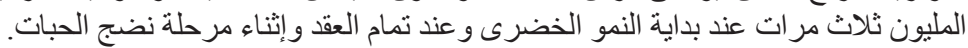

